\title{
Effects of Tillage Practices on Dissemination and Spatial Patterns of Heterodera glycines and Soybean Yield
}

\author{
W. L. Gavassoni, Faculdade de Ciências Agrárias, Universidade Federal da Grande Dourados, Caixa Postal 533, \\ 79.804-970, Dourados MS, Brazil; and G. L. Tylka and G. P. Munkvold, Department of Plant Pathology, Iowa State \\ University, Ames 50011-1020
}

\begin{abstract}
Gavassoni, W. L., Tylka, G. L., and Munkvold, G. P. 2007. Effects of tillage practices on dissemination and spatial patterns of Heterodera glycines and soybean yield. Plant Dis. 91:973-978.

Two field experiments were conducted in central Iowa to assess the effects of tillage on Heterodera glycines dissemination and reproduction and soybean (Glycine max) yield. Plots in both experiments were artificially infested with equivalent numbers of $H$. glycines cysts. In one experiment, plots were left noninfested or received aggregated or uniform infestation, and a susceptible soybean cultivar was grown for 3 years. By the end of the first growing season and through the second, $H$. glycines population densities were consistently greater $(P \leq 0.05)$ in uniformly infested plots than in plots with aggregated infestations. No differences in soybean yield among the treatments were detected. In a second experiment, a $1-\mathrm{m}^{2}$ area of each plot was infested with $H$. glycines cysts, susceptible soybeans were grown for four seasons, and crop residue was managed with either ridge-, conventional-, reduced-, or no-tillage. After 1 year, nematode population densities were significantly $(P \leq 0.05)$ greater in conventional- and reduced-tillage treatments than in no- and ridge-tillage treatments. After 2 years, $H$. glycines had been disseminated $6.9 \mathrm{~m}$ from the infestation site in conventional- and reduced-tillage treatments but only 0.5 and $1.4 \mathrm{~m}$ for no-tillage and ridge-tillage treatments, respectively. After 3 years, $H$. glycines population densities were 10 times greater in conventional- and reduced-tillage treatments than in the no-tillage treatment; conventional-tillage was the only treatment with yield significantly lower $(P \leq 0.05)$ than the noninfested control. Aggregation of $H$. glycines eggs was greater $(P \leq 0.05)$ in no- and ridge-tillage treatments than in conventional- and reduced-tillage treatments. Results indicate tillage can quickly disseminate $H$. glycines in newly infested fields, facilitating more rapid nematode reproduction and subsequent yield loss.
\end{abstract}

Additional keywords: conservation tillage, soybean cyst nematode

Heterodera glycines, the most important pathogen of soybeans (Glycine max (L.) Merr.), was first reported in the United States in 1954 (39). In Iowa, the nematode was first found in 1978 (8). Results of a random survey of soybean fields in Iowa conducted in the mid-1990s indicated that H. glycines was present in $74 \%$ of the fields sampled (40).

From 1986 to 2006, the area of Iowa cropped with no-tillage soybeans increased from about 50,000 ha to more than 1 million ha (2). Although no-tillage crop residue management practices can increase the potential for losses due to soybean diseases caused by pathogens surviving in the infested crop residue $(1,31)$, the impact on $H$. glycines is not fully understood. Be-

Corresponding author: G. P. Munkvold

E-mail: munkvold@iastate.edu

* The $e$-Xtra logo stands for "electronic extra" and indicates that a supplemental figure not included in the print edition is available online.

Accepted for publication 23 February 2007.

doi:10.1094/PDIS-91-8-0973

(C) 2007 The American Phytopathological Society cause of its survival capabilities, host requirements, and dependence on soil movement for dissemination, $H$. glycines may be affected differently than residueborne pathogens. Since $H$. glycines is a widespread and persistent soybean pest and use of conservation tillage practices continues to increase, it is important to understand the effects of different tillage practices on $H$. glycines.

$H$. glycines was present in more tilled fields than no-till fields in three of five states that were randomly sampled in a regional survey in the mid-1990s (40). Furthermore, in the $H$. glycines-infested fields in those states (Illinois, Iowa, and Ohio), the average $H$. glycines soil egg population density was greater in tilled fields than in no-till fields. Although these results might be an indication that no-till soil conditions adversely affect $H$. glycines, no such data were collected to directly test this hypothesis. Several researchers have reported suppression of $H$. glycines populations by no tillage $(9,18,19,35)$. Mechanisms for this suppression have been suggested, but not fully investigated. Most studies were conducted in fields that were naturally infested with $H$. glycines, where the nematode likely was present for several years, and did not take into account the nematode spatial pattern.

Pathogen (or disease) spatial patterns can influence yield losses $(13,14)$. Aggregation of disease or insect pests often has been associated with greater yield loss compared to uniform or random distribution $(3,15)$. However, predicted yield losses have exceeded actual yield losses caused by aggregated populations of plantparasitic nematodes $(24,28,32)$.

The objectives of this research were to elucidate the impact of tillage on dissemination and population densities of $H$. glycines and soybean yield, and to assess the relationship between different spatial patterns of $H$. glycines and soybean yield.

\section{MATERIALS AND METHODS}

Two experiments were conducted in an area of a field initially free of $\mathrm{H}$. glycines and previously cropped to corn (Zea mays L.) and oats (Avena sativa L.) at the Iowa State University (ISU) Crossley Farm (Story County, IA). H. glycines was not detected in soil samples collected in April 1995 from the area of the field where the experiments were established. The soil was a Nicollet fine loamy, mixed, mesic Aquic Hapludolls (35\% sand, $52.5 \%$ silt, $12.5 \%$ clay). One experiment was conducted to evaluate the effect of spatial patterns of $H$. glycines on reproduction of the nematode and yield of soybeans. Another experiment was designed to evaluate the effects of different tillage practices on the dissemination, population density, and spatial pattern of a newly established $H$. glycines infestation within the field.

Inoculum preparation. Some treatments in both experiments included infestation of the soil with $H$. glycines cysts. The nematode was propagated in a greenhouse on susceptible soybean (cv. Corsoy 79) plants. Soybean seeds were planted in 30-cm-diameter clay pots containing $H$. glycines-infested soil. After 8 weeks, plants were clipped at the soil level, the shoots were discarded, and roots were removed. The infested soil was transferred to metal barrels and was kept at approximately 20 to $22^{\circ} \mathrm{C}$. Infected roots were placed on an $850-\mu \mathrm{m}$ sieve nested over a $250-\mu \mathrm{m}$ sieve. Females and cysts of $H$. glycines were removed from the roots by spraying with a stream of tap water and were recovered on the $250-\mu \mathrm{m}$ sieve. The 
$H$. glycines cysts and females recovered from the roots were mixed into the infested soil, and then this inoculum was divided into equal portions, one for each replicate block in each of the experiments. Each portion of inoculum was mixed for $30 \mathrm{~min}$ using a cement mixer; then each portion of the inoculum was further divided into subportions for the number of treatments in the experiment. Each inoculum subportion then was thoroughly mixed and sampled to quantify the nematode population density in order to ensure that plots were infested with equivalent nematode populations. Inoculum was stored at $4^{\circ} \mathrm{C}$ until processed.

To quantify inoculum density, cysts were extracted from the soil samples by elutriation (5). Prior to elutriation, each $100-\mathrm{cm}^{3}$ aliquant of soil was soaked for 30 min in a $15.75 \mathrm{~g} \mathrm{liter}^{-1}$ solution of Electrasol automatic dishwasher detergent (Benckiser Consumer Products Inc., Dunbury, CT) to promote dispersion of soil particles and release of $H$. glycines cysts. Cysts were collected on a $250-\mu \mathrm{m}$ sieve nested beneath an $850-\mu \mathrm{m}$ sieve on the elutriator. Extracted cysts were crushed using a motorized pestle to release eggs (23). Eggs were stained with acid fuchsin and enumerated. The average nematode inoculum density was 17,610 eggs per 100 $\mathrm{cm}^{3}$.

Effects of $\boldsymbol{H}$. glycines spatial pattern. This experiment was conducted from 1996 to 1998. The experimental design was a randomized complete block consisting of three treatments and five replications. The treatments were: noninfested (control), aggregated infestation, and uniform infestation. Plots were $6.1 \mathrm{~m}$ wide $\times 12.2 \mathrm{~m}$ long, consisting of eight soybean rows spaced $0.76 \mathrm{~m}$ apart. In the spring of 1996 , plots were infested with $H$. glycines. Before infestation, all plots were cultivated (5 $\mathrm{cm}$ deep) to facilitate inoculum incorporation. In the aggregated treatment, a 3.0-mdiameter circular area in the center of the plot was infested; and in the uniform treatment, the total area of the plot was infested with $H$. glycines inoculum. Equivalent population densities of $H$. glycines were applied to all plots in both infested treatments. Inoculum was applied using a lawn fertilizer spreader (4). After infestation, inoculum was manually incorporated in each plot using shovels. Population densities in the infested areas, after inoculum incorporation, were 810 and 177 eggs per $100 \mathrm{~cm}^{3}$ of soil in the aggregated and uniformly infested treatments, respectively. Following infestation, plots were planted with the $H$. glycines-susceptible soybean cv. Archer. No tillage was performed in this experiment after the plots were infested, and soybeans were grown for two additional seasons in the experiment. Soil samples were collected from plots in a $2.3-\mathrm{m}$, square grid pattern (18 samples per plot) after planting and again in the fall each year, after the soybeans were harvested. Samples were taken at each intersection of the grid and consisted of three 2.5-cm-diameter, 20 -cm-deep soil cores. H. glycines egg population densities in each soil sample were determined as described for inoculum preparation. When necessary, weeds were removed manually from the plots. Plots were harvested with a plot combine, seed weight and moisture were determined, and yields were converted to $\mathrm{kg} \mathrm{ha}^{-1}$, standardized to $13 \%$ moisture. Lloyd's (20) index of patchiness (LIP), a dispersion index, was calculated as an indicator of the nematode spatial pattern for $H$. glycines population densities at each sampling time. Soybean yield and $H$. glycines egg population density data were subjected to analysis of variance (ANOVA), and Fisher's least significant difference (LSD) test was used to separate means $(\alpha=0.05)$ when significant differences $(P \leq 0.05)$ were detected among treatments. Finally, correlations among soybean yield, nematode population densities, and LIP were performed. Egg population density data were transformed to $\log _{10}(x+1)$ values to standardize the variance prior to statistical analysis, but untransformed data are presented in tables and figures.

Effects of tillage. This experiment was conducted from 1995 to 1998 . The experimental design was a randomized complete block with five treatments and five replications. One treatment was a no-till, noninfested control. The other four treatments all were infested with $H$. glycines and were subjected to one of the following crop residue management practices: notillage, ridge-tillage, conventional-tillage, or reduced-tillage. Conventional tillage consisted of fall chisel plowing $(0.20 \mathrm{~m}$ deep) and spring disking (0.10 $\mathrm{m}$ deep), followed by shallow ( $5 \mathrm{~cm}$ deep) cultivation before planting. In the reduced-tillage treatment, plots were disked in the spring and shallow-cultivated before planting. Ridge tillage is a crop residue management practice used for corn and soybean production in the Midwestern United States that consists of raising the seed bed level above that of the surrounding soil and planting the crop on the same ridges, in the same rows, every year. In the ridge-tillage treatment, the soil was disturbed only for building and maintaining the ridges. Ridges $(0.20 \mathrm{~m}$ high $)$ were built before planting in the spring of 1995 and again in the spring of 1996. The soil in plots under no-tillage was not disturbed except for planting.

Prior to planting, a $1-\mathrm{m}^{2}$ area of each plot was infested with the $H$. glycines inoculum. The inoculum mixture was incorporated into the delimited area to a depth of $5 \mathrm{~cm}$. In the control plots, a noninfested mixture of soil and sand was incorporated into a $1-\mathrm{m}^{2}$ area as done for the infested treatments. The overall $H$. glycines population density in the infested area after in- corporation was 1,800 eggs per $100 \mathrm{~cm}^{3}$ of soil. Tillage operations were performed consistently in an east-to-west direction. Plots were $6.1 \mathrm{~m}$ wide $\times 12.2 \mathrm{~m}$ long with a $1.5-\mathrm{m}$ border between adjacent plots to reduce nematode dispersal into adjacent plots. The infested area of each plot was positioned $4.15 \mathrm{~m}$ from the eastern plot edge and $3.05 \mathrm{~m}$ from the northern plot edge. Each plot had eight soybean rows spaced $0.76 \mathrm{~m}$ apart, and plots were planted each year with the $H$. glycinessusceptible cv. Archer. Plant rows were oriented east-west. A pre-emergence application of a mixture of dicamba ( 0.58 liters $\mathrm{ha}^{-1}$ ) and 2,4-D amine (4.7 liters ha ${ }^{-1}$ ) controlled weeds. All plots were treated with herbicides and, except for the no-tillage plots, were cultivated for supplemental weed control 30 days after planting. Plots under no tillage were weeded manually.

Within a week of planting each spring, soil samples were collected from each plot on a $1.15-\mathrm{m}$, square grid (66 samples per plot). Each soil sample consisted of three 2.5-cm-diameter, 20-cm-deep soil cores taken at the intersection of the grid; the three soil cores were combined and mixed. $H$. glycines egg population densities were determined for each soil sample as described for the previous experiment.

The eight soybean rows in each plot were harvested using a plot combine, then seed weight and moisture were recorded. The plot seed weights were standardized to $13 \%$ moisture for statistical analyses.

For each plot, we recorded the maximum distance from the $H$. glycinesinfested site at which egg population densities greater than 100 eggs per $100 \mathrm{~cm}^{3}$ of soil were detected. Additionally, the LIP dispersion index was calculated for $H$. glycines data and used as an indicator of aggregation of nematode population in the plots. Maps of $H$. glycines distribution in each plot were generated using geostatistical modeling and kriging $\left(\mathrm{GS}^{+}\right.$3.1, Gamma Design Software, Plainwell, MI). Data were analyzed as described for the previous experiment.

\section{RESULTS}

Effects of $\boldsymbol{H}$. glycines spatial pattern. Yields ranged from approximately 2,900 to $3,000 \mathrm{~kg} \mathrm{ha}^{-1}$ in 1996 and decreased significantly $(\alpha=0.05)$ to approximately 2,200 to 2,500 kg ha-1 in 1997 and 1998 . Yields were numerically less in the infested treatments than in the noninfested control in all 3 years of the experiment, but the differences among treatments were not significant (data not shown). H. glycines egg population densities were greater in the uniform treatment than in the aggregated treatment for all sampling times except in the spring of 1998 (Fig. 1). Low numbers of $H$. glycines eggs were recovered from noninfested plots, always significantly less than populations measured in the infested treatments. 
Lloyd's index of patchiness was greater than 1.0 in all treatments and at all sampling dates, indicating aggregation of the egg populations (Table 1). Differences in LIP values between infested treatments were evident in the fall of 1996, spring and fall of 1997, when LIP was significantly greater $(P \leq 0.05)$ in the aggregatedinfested treatment than the uniform infested treatment. The LIP values did not change over the different sampling times and years except in the noninfested treatment.

Linear correlations among soybean yield, mean nematode population density, and LIP were not significant, except for a negative correlation $(P \leq 0.01)$ in 1997 between soybean yield and $H$. glycines population density $(r=-0.79)$ (data not shown).

Effects of tillage. By the end of the first soybean crop season, mean $H$. glycines population densities were significantly greater $(P \leq 0.05)$ in conventional- and reduced-tillage plots than in no-tillage and ridge-tillage plots (Fig. 2). This difference was larger in 1997 and 1998, when population densities in the conventional- and reduced-tillage treatments were more than 10 times those in the no-tillage, infested treatment. There were no differences in $H$. glycines population densities among the other treatments in the 3 years of this study. Population densities increased $(\alpha=$ 0.05 ) annually in the conventional- and reduced-tillage plots, but an increase in population densities in the other treatments was detected only in 1998. Low population densities of $H$. glycines were recovered from soil samples collected in the noninfested treatment plots in all 3 years, likely as a result of contamination by field equipment or development of populations present below the detection level at the beginning of the experiment.

$H$. glycines was detected in the spring of 1996 at greater distances from the original infestation site in the conventional- and reduced-tillage treatments compared to the no-tillage and ridge-tillage treatments (Fig. 3 ). In the spring of 1997, after two crop seasons and following spring tillage, $H$. glycines was detected at the maximum possible distance $(6.9 \mathrm{~m})$ from the infestation site in the conventional- and reducedtillage treatments. Conversely, nematode dissemination in the no-tillage and ridgetillage treatments was not extensive and usually did not approach the edges of the plots. Mean distance of dissemination in the no-till treatment was $0.5 \mathrm{~m}$ and in the ridge-till treatment was $1.4 \mathrm{~m}$. H. glycines eggs were distributed throughout the conventional- and reduced-tillage plots, whereas the nematode was restricted to an area near the original infestation site in the ridge-tillage and no-tillage plots.

Lloyd's index of patchiness values were greater than 1.0, indicating aggregation of the egg populations in all treatments at all sampling times (Table 2). The lowest LIP values consistently occurred in the reduced-tillage and conventional-tillage treatments. In 1996, LIP values were significantly $(\alpha=0.05)$ greater in the ridgetillage treatment compared to reduced tillage. In 1997 and 1998, conventional and reduced tillage had significantly lower indices compared to the other treatments $(\alpha=0.05)$. Between 1996 and 1998, the LIP values decreased significantly in the treatments but did not decrease in the infested no-tillage treatment.

In the first year of this study, there were no differences in soybean yield among treatments (Fig. 4). Differences in yield among treatments became apparent in 1996, when yield was less in the ridgetillage treatment compared to all other treatments except the no-tillage, infested plots. In 1997, the yields of the conventional- and reduced-tillage treatments were significantly less $(\alpha=0.05)$ than yield of conventional-, ridge-, and reduced-tillage

the no-tillage, infested treatment. In 1998, yield in the conventional-tillage treatment was significantly less than yield in the other treatments. In general, yield decreased over time in all treatments. Yields did not differ between no-tillage infested and noninfested treatments in any year of the experiment.

There were significant $(P \leq 0.01)$ negative linear correlations between $H$. glycines population density and soybean yield in 1996 and 1997 ( $r=-0.68$ and $r=-0.61$, respectively) and between LIP and nematode density ( $r=-0.60$ ) in 1998 (data not shown).

\section{DISCUSSION}

H. glycines, like most plant-parasitic nematodes, is dependent on passive mechanisms for dissemination within and between fields (8). During this study, we found that $H$. glycines was disseminated nearly $3.5 \mathrm{~m}$ per year by conventional- and reduced-tillage practices. Population densi-

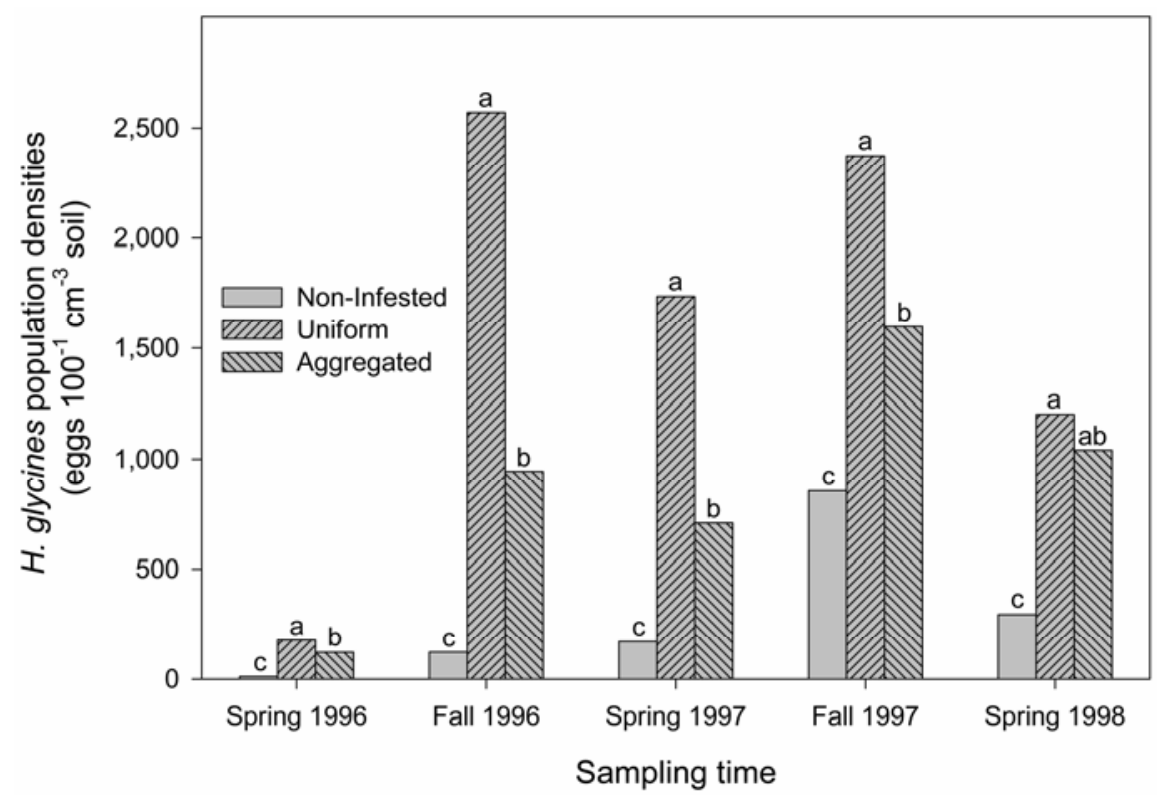

Fig. 1. Heterodera glycines population densities over time in soybean plots subjected to different infestation patterns in spring 1996 at the Iowa State University Crossley Farm (Story County, IA). Values are means of all soil samples collected from five replications per treatment. Samples were collected just prior to planting. Uniform $=H$. glycines cysts introduced throughout each plot; Aggregated $=H$. glycines cysts introduced in a concentrated site within each plot. Numbers of eggs introduced into each plot were equivalent. Bars within each year with the same letter are not significantly different according to Fisher's LSD test $(\alpha=0.05)$. Data were transformed to $\log _{10}(x+1)$ for statistical analysis.

Table 1. Lloyd's index of patchiness for Heterodera glycines egg populations in artificially infested plots in central Iowa ${ }^{\mathrm{y}, \mathrm{z}}$

\begin{tabular}{|c|c|c|c|c|c|}
\hline \multirow[b]{3}{*}{ Treatment } & \multicolumn{5}{|c|}{ Lloyd's index } \\
\hline & \multicolumn{2}{|c|}{1996} & \multicolumn{2}{|c|}{1997} & \multirow{2}{*}{$\begin{array}{c}1998 \\
\text { Spring }\end{array}$} \\
\hline & Spring & Fall & Spring & Fall & \\
\hline Noninfested & 4.9 a C & $9.2 \mathrm{a} A B$ & 14.7 a A & 6.7 a BC & 3.8 a C \\
\hline Uniform & $3.7 \mathrm{a} \mathrm{A}$ & $1.9 \mathrm{~b} \mathrm{~A}$ & $2.9 \mathrm{c} \mathrm{A}$ & $1.8 \mathrm{~b} \mathrm{~A}$ & $2.1 \mathrm{a} \mathrm{A}$ \\
\hline Aggregated & 6.8 a A & $7.1 \mathrm{a} \mathrm{A}$ & $7.3 \mathrm{~b} \mathrm{~A}$ & 5.9 a A & $3.6 \mathrm{a} \mathrm{A}$ \\
\hline
\end{tabular}

${ }^{y}$ Average of five replications. Data were transformed to $\log _{10}(x+1)$ for statistical analysis. Table values are untransformed.

${ }^{z}$ Values followed by the same lowercase letter in columns or uppercase letter in rows are not significantly different according to Fisher's LSD test $(\alpha=0.05)$. 
ties of the nematode increased more in conventional- and reduced-tillage than in ridge- and no-tillage treatments, probably because greater spread of the nematode in the tilled treatments provided access to more soybean plants, which provided a more plentiful food source and facilitated more rapid reproduction than in no tillage and ridge tillage. In the conventional- and reduced-tillage treatments, 70 to $100 \%$ of the plants were exposed to $H$. glycines inoculum by the end of the third crop season, but in most of the no-tillage treatment plots, only 2 to $5 \%$ of the plants were exposed.

The limiting effects of no tillage and ridge tillage on $H$. glycines populations were apparent 1 year after establishment of

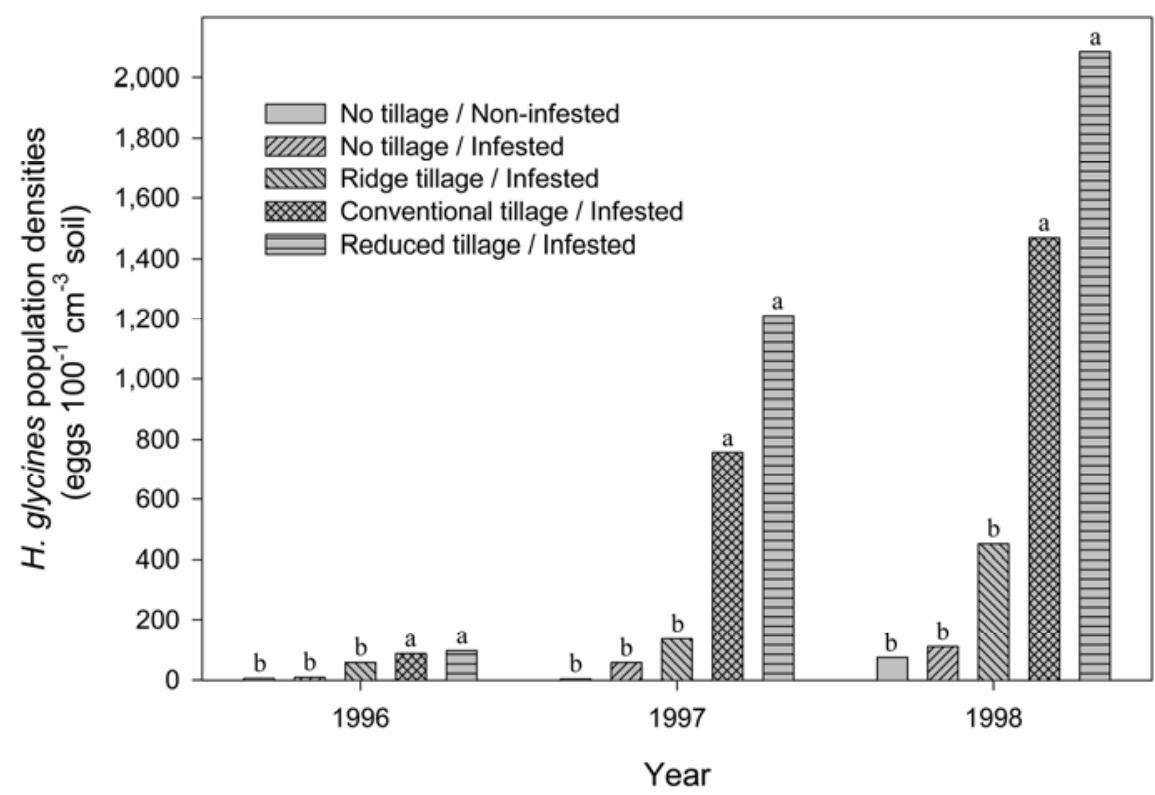

Fig. 2. Population densities of Heterodera glycines in artificially infested (spring 1995) soybean plots under different tillage treatments at the Iowa State University Crossley Farm (Story County, IA). Values are means of all soil samples collected in the spring from five replications per treatment. Samples were collected just prior to planting. Bars within each year with the same letter are not significantly different according to Fisher's LSD test $(\alpha=0.05)$. Data were transformed to $\log _{10}(x+1)$ for statistical analysis.

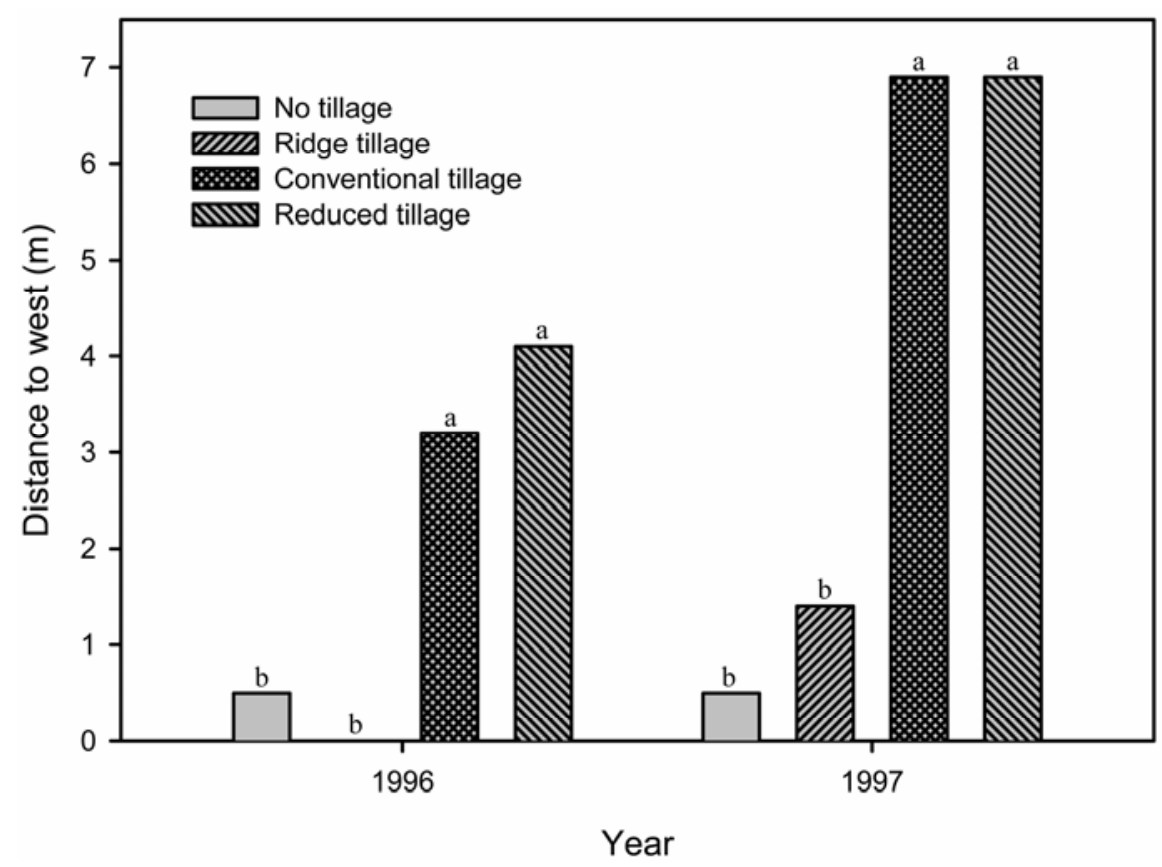

Fig. 3. Distance from the original infestation site (spring 1995) at which Heterodera glycines was detected in soybean plots under different tillage treatments at the Iowa State University Crossley Farm (Story County, IA). Values are means of five replications. Bars within each year with the same letter are not significantly different according to Fisher's LSD test $(\alpha=0.05)$. The maximum possible distance from the infestation site to the plot edge was $6.9 \mathrm{~m}$.

our study. The mechanism of this limited $H$. glycines reproduction probably was restricted dissemination of the nematode and, thus, limited access to a food source. However, other unidentified mechanisms may have been involved. Lower population densities of $H$. glycines in no-tillage compared to conventional-tillage treatments were found by Edwards et al. (9), Hershman and Bachi (12), Koenning et al. (18), Lawrence et al. (19), and Tyler et al. $(35,36)$. But most of these studies were conducted in naturally infested fields, and pre-existing or changing $H$. glycines spatial patterns were not considered. In contrast, Chen et al. (6) found no effect of tillage on nematode population densities, and Noel and Wax (26) reported mixed results, including interacting effects of crop rotation and tillage treatments on $H$. glycines reproduction. It may take several years for lack of tillage to affect nematode population densities (30). However, there have been reports of short-term effects of tillage on $H$. glycines population densities $(36,41)$. In a greenhouse study, with conditions mimicking no tillage and conventional tillage, Young (41) was able to recover more cysts from disturbed soil cores than from undisturbed cores 30 days after planting.

Several mechanisms have been proposed to explain the apparent suppression of $H$. glycines reproduction in no-tillage systems. No tillage results in changes in edaphic environmental factors compared to conventional tillage, such as lower soil temperatures, additional soil water, increased soil organic matter, differences in soil compaction, and increased presence of antagonists $(11,30)$ that, individually or interactively, may have a suppressive effect on the pathogen. In some studies, notillage soybeans were planted in chemically killed wheat or in wheat crop residue $(9,36,41)$. Hershman and Bachi (12) suggested that lower $H$. glycines population densities in no tillage were due to the presence of wheat residue and not due to no tillage per se; however, no such effect was detected in another study of wheat residue effects on $H$. glycines (16).

An alternative explanation for why $H$. glycines population densities differed among tillage systems is the interaction between nematode spatial pattern and population development. This potential mechanism has not been considered in previous studies. The more uniform spatial pattern of $H$. glycines due to conventional tillage in our experiment increased the probability of soybean plants being infected by the nematode compared to the no-tillage treatment, consequently resulting in greater $H$. glycines population densities.

Recovery of $H$. glycines eggs at greater distances in conventional- and reducedtillage plots than in no tillage and ridge tillage illustrates that tillage can quickly 
disseminate the nematode within a field. Dispersal of $H$. glycines by tillage has been suggested by several authors $(29,40)$, but there are few published studies reporting quantitative effects of cultivation on the dissemination of $H$. glycines. Ueda (37) investigated the effects of the application of organic materials on the dispersal of $H$. glycines. Organic materials and cysts of $H$. glycines were incorporated 1 month before planting, and tillage was performed twice a year. $H$. glycines was recovered $4 \mathrm{~m}$ from the infested site in the first year of the study. By the second year, the nematode was recovered $14 \mathrm{~m}$ from the original infested site. In our tillage study, the nematode was moved $6.9 \mathrm{~m}$ from the infestation site after 2 years in the conventional- and reduced-tillage plots. The frequency of tillage activities in our tilled plots was less than that of Ueda (37), possibly explaining the difference between our results and those of Ueda.

Lower Lloyd's index of patchiness values in plots under conventional or reduced tillage compared to ridge- and no-tillage treatments were consistent throughout our experiment. Other studies $(27,34)$ on the impact of tillage on soilborne pathogen propagules have indicated that decreases in the dispersion index values are the result of redistribution of the pathogen population. Similarly, we believe that the reduced LIP values in the conventional- and reducedtillage treatments were a result of the redistribution of egg-bearing cysts within plots. Our previous research in naturally infested fields indicated that tillage practices altered the spatial patterns of $H$. glycines; conventional tillage reduced the aggregation of the population over time, whereas a no-tillage treatment had the most aggregated population, according to semivariance characteristics and varianceto-mean ratios (10).

Nematode population densities probably were too low to cause detectable reductions in yield in the first year of the tillage study. After 1996, however, soybean yield decreased in the conventional-tillage treatment and population densities of $H$. glycines increased. Low soybean yields associated with high nematode population densities and tillage have been reported previously $(19,35,36)$. The relationship between nematode density and yield may not be linear, and this may have limited our ability to detect a relationship using linear correlation. A similar result was reported for effects of tillage on Sclerotinia minor dissemination and lettuce (34). Yields in our no-tillage, infested treatment did not differ from those in the no-tillage, noninfested treatment in any year of the experiment, probably due to the consistently low nematode population densities in the no-tillage, infested treatment.

Decreasing soybean yields in monoculture have been reported previously $(17,18,25)$ and may be due to the cumula- tive effects of soilborne fungal pathogens. The lowest yields in this study occurred in the conventional-tillage treatment, likely as a result of higher nematode populations. Yield of this treatment in 1998 was only about $50 \%$ of the 1995 yield, whereas the 1998 yields in the no-tillage and ridgetillage treatments were approximately 70 and $76 \%$ of the 1995 yields, respectively.

Although differences in population densities of $H$. glycines and yield among treatments were detected after 1995, stunting or chlorosis symptoms sometimes associated with $H$. glycines damage were not observed. This phenomenon is not exceptional. Soybeans may not show obvious symptoms of $H$. glycines parasitism, even when significant yield loss occurs $(21,22,38,42)$.

In the effects of spatial pattern experiment, there was a linkage between spatial pattern and population density. H. glycines population densities were consistently greater in the uniformly infested treatment than in the treatment with aggregated infestation, probably due to the greater ac- cess of nematodes to soybean roots in the uniform treatment. This result supports the hypothesis that reduced nematode populations in no-tillage systems are due to limited spread of the nematode. Because of the correlation between spatial pattern and population density, we were not able to separate the effects of these two factors on soybean yield. It is not possible (and possibly not relevant) to speculate on yield losses that might have occurred with equal $H$. glycines populations but different spatial patterns. One way to address the relationship of spatial pattern and yield would be additional yearly infestations of the aggregated infestation plots to maintain equal population densities between aggregated and uniformly infested treatments.

Yield losses caused by stand-reducing pests may be more severe under an aggregated spatial pattern than a uniform spatial pattern due to better yield compensation in a uniform pest attack (7). We believe that in the $H$. glycines-soybean pathosystem, yield compensation is unlikely to occur, regardless of the nematode spatial pattern.

Table 2. Effects of different tillage systems on Lloyd's index of patchiness for Heterodera glycines egg populations in artificially infested central Iowa plots $^{\mathrm{y}, \mathrm{z}}$

\begin{tabular}{lccc}
\hline & \multicolumn{3}{c}{ Lloyd's index } \\
\cline { 2 - 4 } Treatment & $\mathbf{1 9 9 6}$ & $\mathbf{1 9 9 7}$ & $\mathbf{1 9 9 8}$ \\
\hline No-tillage / infested & $13.3 \mathrm{ab} \mathrm{A}$ & $19.7 \mathrm{a} \mathrm{A}$ & $12.8 \mathrm{a} \mathrm{A}$ \\
No-tillage / noninfested & $11.4 \mathrm{ab} \mathrm{A}$ & $12.3 \mathrm{a} \mathrm{A}$ & $5.7 \mathrm{~b} \mathrm{~B}$ \\
Ridge / infested & $15.7 \mathrm{a} \mathrm{A}$ & $15.8 \mathrm{a} \mathrm{A}$ & $6.7 \mathrm{~b} \mathrm{~B}$ \\
Conventional / infested & $10.4 \mathrm{ab} \mathrm{A}$ & $4.6 \mathrm{~b} \mathrm{AB}$ & $2.0 \mathrm{~b} \mathrm{~B}$ \\
Reduced / infested & $5.8 \mathrm{~b} \mathrm{~A}$ & $3.5 \mathrm{~b} \mathrm{~B}$ & $2.3 \mathrm{~b} \mathrm{C}$ \\
\hline
\end{tabular}

${ }^{y}$ Average of five replications. Data were transformed to $\log _{10}(x+1)$ for statistical analysis. Table values are untransformed.

${ }^{\mathrm{z}}$ Values followed by the same lowercase letter in columns or uppercase letter in rows are not significantly different according to Fisher's LSD test $(\alpha=0.05)$.

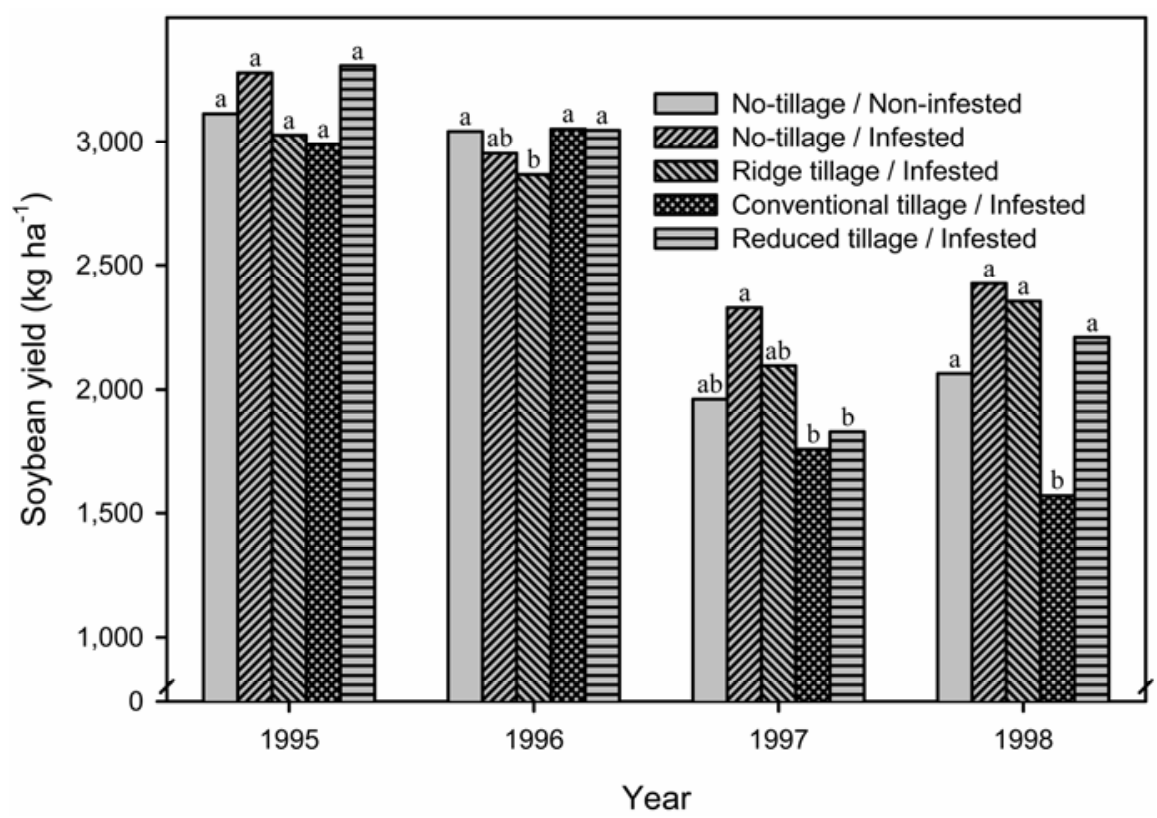

Fig. 4. Soybean yields in plots artificially infested with Heterodera glycines and under different tillage systems at the Iowa State University Crossley Farm (Story County, IA). Values are means of five replications. Bars within each year with the same letter are not significantly different according to Fisher's LSD test $(\alpha=0.05)$ 
Published reports on soybean yield compensation rely on stand-reducing factors. $H$. glycines rarely causes stand reduction (33). It is unlikely that a plant heavily infected by $H$. glycines would occur adjacent to a noninfected plant that could compensate for the yield loss of the neighboring, diseased plant.

Our results illustrate the utility of notillage practices in the management of $H$. glycines and may provide a key explanation for the association of no tillage with lower population densities of the nematode. Adoption of no-tillage in fields where the nematode has not been detected or in recently infested fields should limit dissemination, reproduction, and yield losses caused by $H$. glycines.

\section{ACKNOWLEDGMENTS}

This research was partially funded by soybean checkoff funds administered by the Iowa Soybean Association. W. L. Gavassoni was supported by fellowships from the Fundação Coordenação de Aperfeiçoamento de Pessoal de Nível Superior and Universidade Federal de Mato Grosso do Sul, Brazil. We are grateful to M. Kaiser for statistical advice and to W. M. Carlton, K. Gillette, J. O'Mara, J. Shriver, D. Soh, and S. Souhrada for technical assistance.

\section{LITERATURE CITED}

1. Adee, E. A., Grau, C. R., and Oplinger, E. S. 1997. Population dynamics of Phialophora gregata in soybean residue. Plant Dis. 81:199-203.

2. Anonymous. 2006. Crop Residue Management: Iowa. Conservation Technology and Information Center, West Lafayette, IN. Online publication.

3. Bardner, R., and Fletcher, K. E. 1974. Insect infestations and their effects on the growth and yield of field crops: A review. Bull. Entomol. Res. 64:141-160.

4. Browde, J. A., Tylka, G. L., Pedigo, L. P., and Owen, M. D. K. 1994. A method for infesting small field plots with soybean cyst nematode. Agron. J. 86:585-587.

5. Byrd, D. W., Jr., Barker, K. R., Ferris, H., Nusbaum, C. J., Griffin, W. E., Small, R. H., and Stone, C. A. 1976. Two semi-automatic elutriators for extracting nematodes and certain fungi from soil. J. Nematol. 8:206-212.

6. Chen, S. Y., Stienstra, W. C., Lueschen, W. E., and Hoverstad, T. R. 2001. Response of Heterodera glycines and soybean cultivar to tillage and row spacing. Plant Dis. 85:311-316.

7. Crawley, M. J. 1983. Herbivory. Blackwell Scientific Publications, Oxford.

8. Edwards, D. I. 1988. The soybean cyst nematode. Pages 81-86 in: Soybean Diseases of the North Central Region. T. D. Wyllie and H. Scott, eds. American Phytopathological Society, St. Paul, MN.

9. Edwards, J. H., Thurlow, D. L., and Eason, J.
T. 1988. Influence of tillage and crop rotation on yields of corn, soybean, and wheat. Agron. J. 80:76-80.

10. Gavassoni, W. L., Tylka, G. L., and Munkvold, G. P. 2001. Relationships between tillage and spatial patterns of Heterodera glycines. Phytopathology 91:534-545.

11. Griffith, D. R., Mannering, J. V., and Box, J. E. 1986. Soil and moisture management with reduced tillage. Pages 19-57 in: No-Tillage and Surface-Tillage Agriculture - The Tillage Revolution. M. A. Sprague and G. B. Triplett, eds. John Wiley \& Sons, New York.

12. Hershman, D. E., and Bachi, P. R. 1995. Effect of wheat residue and tillage on Heterodera glycines and yield of doublecrop soybeans in Kentucky. Plant Dis. 77:780-786.

13. Hughes, G. 1988. Modeling the effect of spatially heterogeneous pest injury on crop yields. Crop Res. 28:137-144.

14. Hughes, G. 1988. Spatial heterogeneity in crop loss assessment models. Phytopathology 78:883-884.

15. James, W. C. 1974. Assessment of plant diseases and losses. Annu. Rev. Phytopathol. 12:27-48.

16. Koenning, S. R., and Anand, S. C. 1991. Effects of wheat and soybean planting date on Heterodera glycines population dynamics and soybean yield with conventional tillage. Plant Dis. 75:301-304.

17. Koenning, S. R., Schmitt, D. P., and Barker, K. R. 1993. Effects of cropping systems on population density of Heterodera glycines and soybean yield. Plant Dis. 77:780-786.

18. Koenning, S. R., Schmitt, D. P., and Barker, K. R. 1995. Impact of crop rotation and tillage system on Heterodera glycines population density and soybean yield. 1995. Plant Dis. 79:282-286.

19. Lawrence, G. W., Johnson, B. B., and McLean, K. S. 1990. Influence of tillage systems on nematode population development and soybean yield responses. (Abstr.) Phytopathology 80:436.

20. Lloyd, M. 1967. Mean crowding. J. Animal Ecol. 36:1-30.

21. Niblack, T. L. 2005. Soybean cyst nematode management revisited. Plant Dis. 89:10201026.

22. Niblack, T. L., Baker, N. K., and Norton, D. C. 1992. Soybean yield losses due to Heterodera glycines in Iowa. Plant Dis. 76:943-948.

23. Niblack, T. L., Heinz, R. D., Smith, G. S., and Donald, P. A. 1993. Distribution, density, and diversity of Heterodera glycines in Missouri. J. Nematol. 25:880-886.

24. Noe, J. P., and Barker, K. R. 1985. Overestimation of yield loss of tobacco caused by the aggregated spatial pattern of Meloidogyne incognita. J. Nematol. 17:245-251.

25. Noel, G. R., and Edwards, D. I. 1996. Population development of Heterodera glycines and soybean yield in soybean-maize rotations following introduction into a noninfested field. J. Nematol. 28:335-342.

26. Noel, G. R., and Wax, L. M. 2003. Population dynamics of Heterodera glycines in conven- tional tillage and no-tillage soybean/corn cropping systems. J. Nematol. 35:104-109.

27. Olanya, O. M., and Campbell, C. L. 1988 Effects of tillage on the spatial patterns of microsclerotia of Macrophomina phaseolina. Phytopathology 78:217-221.

28. Perry, J. N. 1983. Effects of spatial heterogeneity on Jone's model for cyst-nematode population dynamics and crop root damage. J. Appl. Ecol. 20:849-856.

29. Sasser, J. N. 1989. Distribution and means of spread. Pages 47-48 in: Plant Parasitic Nematodes: The Farmer's Hidden Enemy. North Carolina State University, Raleigh.

30. Schmitt, D. P. 1992. Population dynamics. Pages 51-59 in: Biology and Management of the Soybean Cyst Nematode. R. D. Riggs and J. A. Wrather, eds. American Phytopathological Society, St. Paul, MN.

31. Schmitthenner, A. F. 1985. Problems and progress in control of Phytophthora root rot of soybean. Plant Dis. 69:362-367.

32. Seinhorst, J. W. 1973. The relation between nematode distribution in a field and loss in yield at different average nematode densities Nematologica 19:421-427.

33. Sinclair, J. B., and Backman, P. A. 1989. Compendium of Soybean Diseases. 3rd ed. American Phytopathological Society, St. Paul, MN.

34. Subbarao, K. V., Koike, S. T., and Hubbard, J. C. 1996. Effects of deep plowing on the distribution and density of Sclerotinia minor sclerotia and lettuce drop incidence. Plant Dis. 80:28-33.

35. Tyler, D. D., Chambers, A. Y., and Young, L. D. 1987. No-tillage effects on population dynamics of soybean cyst nematode. Agron. J. 79:799-802.

36. Tyler, D. D., Overton, J. R., and Chambers, A. Y. 1983. Tillage effects on soil properties, diseases, cyst nematodes, and soybean yields. J. Soil Water Conserv. 38:374-376.

37. Ueda, Y. 1996. The effects of soil application of organic materials on the dispersal, root penetration of soybean cyst nematode Het erodera glycines and on yield loss of soybean. Japanese J. Nematol. 26:29-31.

38. Wang, J., Niblack, T. L., Tremaine, J. N., Wiebold, W. J., Tylka, G. L., Marett, C. C., Noel, G. R., Myers, O., and Schmidt, M. E. 2003. The soybean cyst nematode reduces soybean yield without causing obvious symptoms. Plant Dis. 87:623-628.

39. Winstead, N. N., Skotland, C. B., and Sasser, J. N. 1955. Soybean-cyst nematode in North Carolina. Plant Dis. Rep. 39:9-11.

40. Workneh, F., Tylka, G. L., Yang, X. B., Faghihi, J., and Ferris, J. M. 1999. Regional assessment of soybean brown stem rot, Phy tophthora sojae, and Heterodera glycines using area-frame sampling: Prevalence and effects of tillage. Phytopathology 89:204-211.

41. Young, L. D. 1987. Effects of soil disturbance on reproduction of Heterodera glycines. J. Nematol. 19:141-142.

42. Young, L. D. 1996. Yield loss in soybean caused by Heterodera glycines. Suppl. J. Nematol. 28:604-607. 